\title{
IgG and IgG2 antibodies from cattle naturally infected with Anaplasma marginale recognize the recombinant vaccine candidate antigens VirB9, VirB10, and elongation factor-Tu
}

\author{
Flábio R Araújo/ , Cátia M Costa1', Carlos AN Ramos², Thais A Farias, Ingrid leda F de Souza, \\ Elaine SP Melo², Carina Elisei, Gracia MS Rosinha, Cleber O Soares, Stênio P Fragoso ${ }^{3}$, \\ Adivaldo H Fonseca ${ }^{1}$
}

Embrapa Gado de Corte, Caixa Postal 154, 79002-970 Campo Grande, MS, Brasil ${ }^{1}$ Universidade Federal Rural do Rio de Janeiro, RJ, Brasil

${ }^{2}$ Universidade Federal de Mato Grosso do Sul, Campo Grande, MS, Brasil ${ }^{3}$ Instituto de Biologia Molecular do Paraná, Curitiba, PR, Brasil

Anaplasma marginale is an important vector-borne rickettsia of ruminants in tropical and subtropical regions of the world. Immunization with purified outer membranes of this organism induces protection against acute anaplasmosis. Previous studies, with proteomic and genomic approach identified 21 proteins within the outer membrane immunogen in addition to previously characterized major surface proteinla-5 (MSPla-5). Among the newly described proteins were VirB9, VirB10, and elongation factor-Tu (EF-Tu). VirB9, VirB10 are considered part of the type IV secretion system (TFSS), which mediates secretion or cell-to-cell transfer of macromolecules, proteins, or DNAprotein complexes in Gram-negative bacteria. EF-Tu can be located in the bacterial surface, mediating bacterial attachment to host cells, or in the bacterial cytoplasm for protein synthesis. However, the roles of VirB9, VirB10, and TFSS in A. marginale have not been defined. VirB9, VirB10, and EF-Tu have not been explored as vaccine antigens. In this study, we demonstrate that sera of cattle infected with A. marginale, with homologous or heterologous isolates recognize recombinant VirB9, VirB10, and EF-Tu. IgG2 from naturally infected cattle also reacts with these proteins. Recognition of epitopes by total $\operatorname{Ig} G$ and by IgG2 from infected cattle with A. marginale support the inclusion of these proteins in recombinant vaccines against this rickettsia.

Key words: Anaplasma marginale - VirB - elongation factor-Tu - recombinant proteins - vaccine - cattle

Anaplasmosis is an important vector-borne rickettsial disease of ruminant livestock in tropical and subtropical regions of the world (Palmer et al. 1986), including South America (Barros et al. 2005). The disease is caused by Anaplasma marginale, an ehrlichial pathogen of the genogroup II (Dumler et al. 2001), and is characterized by fever, anemia, general weakness, pallor of mucous membranes, weight loss (Ajayi et al. 1978), abortion (Correa et al. 1978), decreased milk production, and mortality during the acute phase of infection (Palmer et al. 1986).

Current methods of control of anaplasmosis include immunization of susceptible animals with infected blood from carrier cattle (premunition) or infection with attenuated live or less pathogenic Anaplasma centrale live vaccines (Kocan et al. 2003). Such immunogens are derived from blood of infected cattle, resulting in a high cost of production and risks of widespread transmission of unknown or newly emergent pathogens (Palmer et al. 1999). Consequently, current research emphasizes the identification of the effectors of protective immunity and of the $A$. marginale epitopes targeted by these effectors, with the goal of developing a standardized and safe vaccine (Palmer et al. 1999).

Financial support: FUNDECT, Embrapa, CNPq

+ Corresponding author: flabio@enpgc.embrapa.br

Received 20 September 2007

Accepted 22 February 2008
Cattle immunized with initial bodies or their outer membrane showed significantly less reduction of packed cell volumes and lower rickettsemias after challenge with virulent $A$. marginale, as compared with non-immunized animals (Montenegro-James et al. 1991, Tebele et al. 1991, Rodriguez et al. 2000).

In the outer membrane of $A$. marginale, six major surface proteins (MSP) were initially characterized: MSP1a, MSP1b, MSP2, MSP3, MSP4, and MSP5 (Palmer \& McGuire 1984, Barbet et al. 1987, Oberle et al. 1988, Tebele et al. 1991, Oberle \& Barbet 1993). However, none of these recombinant proteins, individually or collectively, recreated the immunoprotective capacity of the outer membrane (Brayton et al. 2006). Therefore, complete genome sequencing and proteomic analysis of the A. marginale membrane were undertaken (Brayton et al. 2005, Lopez et al. 2005) to create a database that could be used to identify membrane proteins that might be useful for vaccine development.

Genomic analysis revealed a series of new genes of membrane proteins, such as the set of 14 outer membrane proteins genes (omps 1-14) (Brayton et al. 2005). However, proteomic analysis revealed that many proteins that were not annotated as membrane proteins were actually located or associated with $A$. marginale membrane, such as AM097 - conjugal transfer protein, AM956 - PepA cytosol amino peptidase, elongation factor-Tu (EF-Tu), VirB9, VirB10, AM197, AM854, AM127, and AM387 (Lopez et al. 2005). 
These proteins are potential immunogens, as they were recognized by immunoglobulin G2 (IgG2) from three cattle immunized with outer membrane of $A$. marginale (Lopez et al. 2005). In A. marginale outer membrane-vaccinated cattle, VirB9 and VirB10 also stimulate proliferation of memory T-lymphocytes 0 and secretion of Interferon-gamma (IFN- $\gamma$ ) (Lopez et al. 2007). Protective immunity against this rickettsia has been hypothesized to require production of IFN- $\gamma$ and induction of IgG2 against outer membrane protein epitopes (Brown et al. 1998).

Nevertheless, these proteins may not perform the same way in naturally infected cattle as they did in outer membrane-immunized cattle, and this is a key information to clarify the potential of VirB9 and VirB10, and EF-Tu as immunogens.

In this paper we describe the production of recombinant VirB9, VirB10, and EF-Tu from a Brazilian isolate of $A$. marginale and determine if cattle naturally infected with Brazilian homologous and heterologous isolates of this pathogen produced IgG and IgG2 antibody responses against these recombinant proteins.

\section{MATERIALS AND METHODS}

A. marginale isolate - Initial bodies were isolated from erythrocytes from a splenectomized calf experimentally infected with a Brazilian isolate of $A$. marginale (state of Rio Grande do Norte), as described by Palmer and McGuire (1984). Blood was collected in vacuum tubes with heparin when rickettsemia reached $44 \%$.

Genomic DNA extraction - DNA was purified from $300 \mu \mathrm{l}$ of infected blood by Easy DNA kit (Invitrogen, US). The concentration of extracted DNA and the $\mathrm{A}_{260}$ ' $\mathrm{A}_{280}$ ratio were determined on a GeneQuant spectrophotometer (Amersham Pharmacia Biotech, USA).

Amplification of VirB9, VirB10 and EF-Tu - Primers were designed with the Oligoperfect (Invitrogen) program to amplify the whole ORFs of VirB9, VirB10 and EF-Tu, based on the Saint Maries isolate genome (NCBI accession nr: NC_004842). These primers were VirB9-F (5' TGAATTTCTATAAAAACTTGCTTGC 3'), VirB9-R (5' TCAAAGCACCGTATTCACTACTTC 3'), VirB10-F (5'-TTGAGTTTAGGGATGTCAGACG 3'), VirB10-R (5' CTACCTACGCACCGCCTC 3'), EF-Tu-F (5' ATGACAGAAGGGAGAAAGCC 3'), and EF-Tu-R (5' CTACTCCAAAATCTCAGTTATGATACC 3'). Polymerase chain reaction (PCR) amplification reaction mixtures were prepared in a volume of $50 \mu \mathrm{l}$, containing $10 \mathrm{mM}$ Tris- $\mathrm{HCl}$ (pH 8.5), $50 \mathrm{mM} \mathrm{KCl}, 1.5 \mathrm{mM} \mathrm{MgCl}, 0.2 \mathrm{mM}$ (each) de-

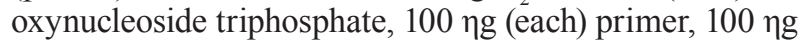
of genomic DNA, and 2.5 U of Taq DNA polymerase (Cenbiot, Brazil). Amplifications were performed in a Mastercycler thermocycler (Eppendorf, Germany) as follows: 35 cycles at $94^{\circ} \mathrm{C}$ for $1 \mathrm{~min}$ (denaturation), $55^{\circ} \mathrm{C}$ for $1 \mathrm{~min}$ (annealing), and $72^{\circ} \mathrm{C}$ for $1 \mathrm{~min}$ and $40 \mathrm{~s}$ (extension), and the last cycle was $72^{\circ} \mathrm{C}$ for $7 \mathrm{~min}$ (extension). PCR products were analyzed by electrophoresis in $1 \%$ agarose gel, stained with ethidium bromide $(0.5 \mu \mathrm{g} / \mathrm{ml})$.

Cloning of VirB9, VirB10 and EF-Tu - PCR amplicons were cloned in plasmid pGEM-T Easy (Promega, US), according to the manufacturer's instructions. The recombinant plasmid was used to transform Escherichia coli $\mathrm{DH} 5 \alpha$ cells. Recombinant plasmids were double digested with EcoR I and inserts were subcloned in frame into EcoR I site of pET-47b expression plasmid (Novagen, US). DH5 $\alpha$ cells were transformed with recombinant plasmids and insert orientation was checked by colony PCR with T7 forward primer and VirB9, VirB10 or EF-Tu reverse primers. Selected plasmids were used to transform Rosetta cells (Novagen, USA).

Production of recombinant VirB9, VirB10, and EF$T u$ - Overnight $5 \mathrm{ml}$ cultures of $E$. coli Rosetta carrying the recombinant plasmids grown in liquid selective Circlegrow (CG) (Bio 101, US) medium containing Kanamicin $(25 \mu \mathrm{g} / \mathrm{ml})$ and Chloranphenicol $(34 \mu \mathrm{g} / \mathrm{ml})$ were cultured in $250 \mathrm{ml}$ of this medium at $37^{\circ} \mathrm{C}$ and $250 \mathrm{rpm}$, until optical densities reached $0.6(600 \mathrm{\eta m})$. Isopropyl- $\beta$-D-thiogalactopyranoside (IPTG) was added at a final concentration of $1 \mathrm{mM}$. The cultures were allowed to grow for $6 \mathrm{~h}$. After this, E. coli cells were recovered by centrifugation at $10,000 \mathrm{~g}$ for $10 \mathrm{~min}$. Pellets were suspended in $10 \mathrm{ml}$ of $50 \mathrm{mM}$ phosphate buffer and then frozen in liquid nitrogen. After thawing at $4^{\circ} \mathrm{C}$, the suspension was sonicated (Sonifier 250, Branson, USA - output 40) for 6 x $20 \mathrm{~s}$ on ice. After SDS-PAGE, recombinant proteins were visualized by Coomassie blue staining. Also, Western blots with recombinant proteins and monoclonal antibody (MoAb) anti-histidine were performed. MoAb anti-histidine (ref. 27-4710-01, Amersham Pharmacia, USA) was diluted 1:6,000 in phosphate-buffered saline (PBS) with $0.01 \%$ of tween 20 (PBST) and incubated for $1 \mathrm{~h}$, with shaking. After three washes with PBST, anti-mouse IgG/peroxidase (ref. A-9044, Sigma, USA), diluted 1:2,000 in PBST, was incubated for $30 \mathrm{~min}$, with shaking. The reactions were revealed with diaminobenzidine (DAB, Sigma) $/ \mathrm{H}_{2} \mathrm{O}_{2}$.

Purification of recombinant proteins - The recombinant proteins VirB9, VirB10, and EF-Tu were purified from $E$. coli Rosetta cell lysates by chromatography with agarose- $\mathrm{Ni}^{2+}$ resin (ProBond, Invitrogen). The purity of the recombinant proteins was assessed by SDS-PAGE.

Standardization of the enzyme-linked immune sorbent assay (ELISAs) - Optimal dilutions of antigen, sera and conjugate for ELISAs with VirB9, VirB10, and EF-Tu were determined by testing four sera negative for $A$. marginale antibodies, from cattle kept in an isolation area of Embrapa Beef Cattle Research Center, and four sera positive for $A$. marginale antibodies, from experimentally infected cattle. Status of $A$. marginale infection was defined by PCR for MSP5 gene.

ELISAs with VirB9, VirB10, and EF-TU - 96-well plates (ref. 3590, Costar) were adsorbed with $3.25 \mathrm{\eta g} /$ well of VirB9 and VirB10, and $2.0 \mathrm{\eta g} / \mathrm{well}$ of EF-Tu, diluted in Dulbelcco's phosphate buffer, $\mathrm{pH}$ 7.2, for $12 \mathrm{~h}$, at $4^{\circ} \mathrm{C}$. Plates were blocked with PBST with $5 \%$ swim milk, for $1 \mathrm{~h}$, at $37^{\circ} \mathrm{C}$. After five washes with PBST, positive and negative sera and test sera (in duplicate), diluted 1:400 in PBST, were incubated for $60 \mathrm{~min}$ at $37^{\circ} \mathrm{C}$. Plates were then washed five times with PBST, and $100 \mu \mathrm{l} /$ well of rabbit anti-bovine IgG horseradish peroxidase conju- 
gate (ref. A-7414, Sigma), diluted 1:10,000 in PBST, were added. Plates were incubated for $30 \mathrm{~min}$ at $37^{\circ} \mathrm{C}$ and after five washes with PBST, the chromogen/substrate o-phenylene diamine dihydrochloride (OPD; Sigma)/ $\mathrm{H}_{2} \mathrm{O}_{2}$ was added. The reaction was stopped by addition of $50 \mu \mathrm{l} / \mathrm{well}$ of $\mathrm{H}_{2} \mathrm{SO}_{4}(2.5 \mathrm{~N})$ and results were read on a EL-800 ELISA reader (Bio-Tek), with a 490 ๆm filter. Cutoffs were determined according to Frey et al. (1998).

Serum samples were from 72 Aberdeen-Angus cattle experimentally infected with Rio Grande do Norte homologous isolate of A. marginale; from 72 Anaplasmafree cattle, defined by PCR for MSP5 gene (Silva et al. 2006); from 70 cattle naturally infected with this rickettsia from state of Alagoas, positive by indirect ELISA with MSP5 (Melo et al. 2007); and from 72 seronegative cattle, all of which were analyzed by ELISAs with VirB9, VirB10, and EF-Tu for specific IgG.

For titration of specific IgG2, anti-VirB9, VirB10, and EF-Tu IgG positive sera from 12 cattle naturally infected with A. marginale from state of Alagoas were tested by ELISA. The protocol of this test was essentially the same used for total $\operatorname{IgG}$, except that sera were diluted from 1:100 to 1:4,000; monoclonal anti-bovine IgG2 (MCA626, Serotec, US) was diluted 1:5,000, and rabbit anti-mouse $\operatorname{IgG}$ horseradish conjugate (A-9044, Sigma) was diluted 1:10,000.

Statistical analysis - Results of IgG2 titration were compared among groups (ELISAs with VirB9, VirB10, and EF-Tu) with Friedman and Tukey tests, with a degree of confidence of $95 \%$.

\section{RESULTS AND DISCUSSION}

Amplification of VirB9, VirB10, and EF-Tu - The amplification of VirB9, VirB10, and EF-Tu by PCR resulted in fragments of $840,1,338$, and $1,118 \mathrm{bp}$, respectively (Fig. 1). The size of the amplified genes match with the same genes in the Saint Maries isolate. Partial sequencing of VirB9, VirB10, and EF-Tu from different Brazilian isolates of $A$. marginale suggests that they are conserved (unpublished observations). VirB9 and VirB10 were found to be highly conserved with orthologous proteins in Anaplasma phagocytophilum, Ehrlichia chaffeensis, and Ehrlichia canis (Lopez et al. 2007).

VirB9 and VirB10 are components of the TFSS. In other Gram-negative bacteria, TFSS proteins form channels and facilitate secretion of molecules, and are required for intracellular survival (Lopez et al. 2007). In prokaryotes, EF-Tu can form ternary complexes with GTP and aminoacyl-tRNA. Aminoacyl-tRNA molecule that is tightly bound to EF-Tu pairs transiently with the codon at the A-site in the small subunit of the ribosome. During this step, the tRNA occupies a hybrid-binding site on the ribosome. The codon-anticodon pairing triggers GTP hydrolysis by EF-Tu causing it to dissociate from the aminoacyl-tRNA, which now enters the A-site and can participate in chain elongation (Nilsson \& Nissen 2005). Nevertheless, EF-Tu can be located in the bacterial surface, mediating attachment to host cells (Granato et al. 2004). Due to the crucial importance of VirBs and EF-Tu for bacteria, the genes for these three proteins are expected to be conserved.

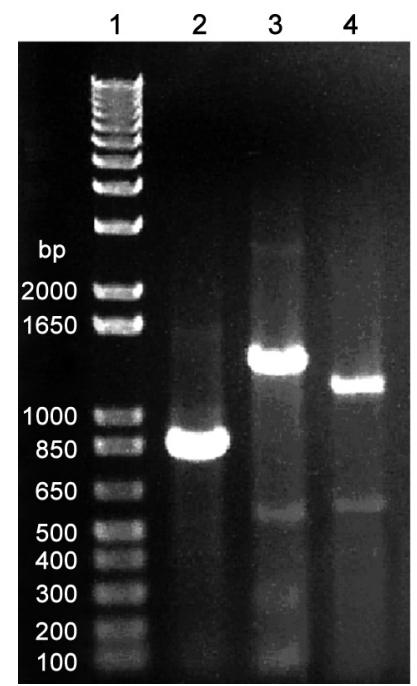

Fig.1: amplification of virB9, virB10, and ef-tu of Anaplasma marginale by PCR. Lanes - 1: $1 \mathrm{~kb}$ plus ladder (Invitrogen); 2: virb9; 3: virb10; 4: ef-tu.

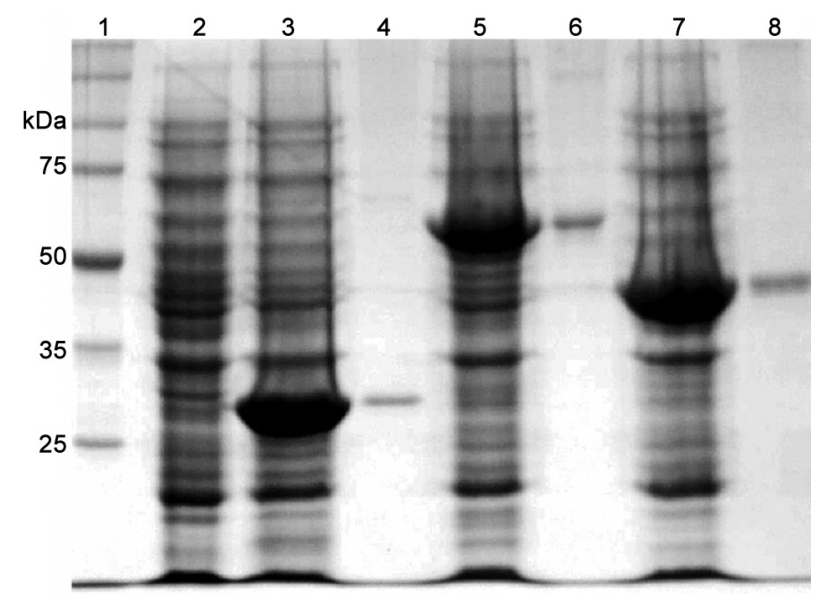

Fig. 2: coomassie blue stained SDS-PAGE profile of Escherichia coli Rosetta extracts expressing VirB9, VirB10, and EF-Tu from a Brazilian isolate (Rio Grande do Norte) of Anaplasma marginale. Lanes - 1: molecular mass marker (Promega ref V8491); 2: extract of E. coli Rosetta, 3: Rosetta cells transformed with pET-47b/VirB9; 4: purified recombinant VirB9; 5: Rosetta cells transformed with $\mathrm{pET}-47 \mathrm{~b} /$ VirB10; 6: purified recombinant VirB10; 7: Rosetta cells transformed with pET-47b/EF-Tu; 8: purified recombinant EF-TU.

Production of recombinant EF-TU, VirB9, and VirB10 - Expression of VirB9, VirB10, and EF-Tu were confirmed by SDS-PAGE, with observed protein bands of $29 \mathrm{kDa}, 55 \mathrm{kDa}$ and $46 \mathrm{kDa}$, respectively (Fig. 2), which are approximately the predicted molecular weights based on the DNA sequences of the genes and coding fragments of the vector.

ELISAs with EF-TU, VirB9, and VirB10 - Of 72 serum samples from cattle experimentally infected with A. marginale from Rio Grande do Norte (homologous isolate), defined by PCR for MSP5, $72(100 \%)$ were also positive for anti-VirB9, -VirB10 and -EF-Tu antibodies (Table I). Of 72 sera from cattle free of infection with $A$. 
marginale, $72(100 \%)$ were negative for VirB10 and 71 (98.6\%) were negative for VirB9 and EF-Tu. Of 70 serum samples from cattle naturally infected with $A$. marginale from state of Alagoas (heterologous isolate), defined by ELISA with MSP5, $61(87.1 \%)$ were also positive for VirB9, VirB10 and EF-Tu antibodies (Table II). All 70 sera from anti-MSP5 antibody-negative cattle from the same region were also negative for VirB9, VirB10 and EF-Tu antibodies. These data show that VirB9, VirB10 and EF-Tu are immunogenic in experimentally or naturally infected cattle, as they elicited a specific humoral response that could be detected by ELISA with recombinant proteins. Secondly, epitopes were conserved between heterologous isolates of $A$. marginale (Rio Grande do Norte and Alagoas). Both characteristics are important for the development of immunogens, especially in continental countries like Brazil.

The CD4 T cell type I response involving production of interferon- $\gamma$ and resulting in activation of macrophages has been associated with immunity against intra-erythrocytic pathogens (Brown et al. 1998, 2001). The Thl response also stimulates production of the immunoglobulin G2 isotype by B cells, which increases opsonization and consequently phagocytosis by activated macrophages (Brown et al. 1998). Therefore, conservation of B cell epitopes between and within strains is crucial for the clearance of Anaplasma because antibody specificity is important in this process.

IgG2 antibodies specific for recombinant VirB9, VirB10 and EF-Tu were detected in naturally infected cattle, with mean titers of 950, 850 and 1,250, respectively (Fig. 3). IgG2 responses to EF-Tu were significantly higher $(p<0.05)$ than responses to VirB10, however there were no differences between the magnitudes of IgG2 responses against EF-Tu and VirB9 and against VirB9 and VirB10 $(p>0.05)$. These data corroborate findings of Lopez et al. (2005) which demonstrated that VirB9, VirB10 and EF-Tu are recognized by $\operatorname{IgG} 2$ of $A$. marginale outer membrane-vaccinated cattle. These proteins also stimulate memory T-lymphocyte proliferation and IFN- $\gamma$ secretion Lopez et al. (2007). This is important, as protective immune response might require the interaction of humoral and cellular components.

Recognition of VirB9, VirB10 and EF-Tu by antibodies from cattle infected with homologous and heterologous isolates, and by $\mathrm{IgG} 2$ from cattle naturally infected with this rickettsia support the inclusion of these proteins in vaccines being developed against $A$. marginale. Experiments of immunization with these recombinant proteins are been conducted at Embrapa Beef Cattle in order to assess their protective potential against virulent challenge.

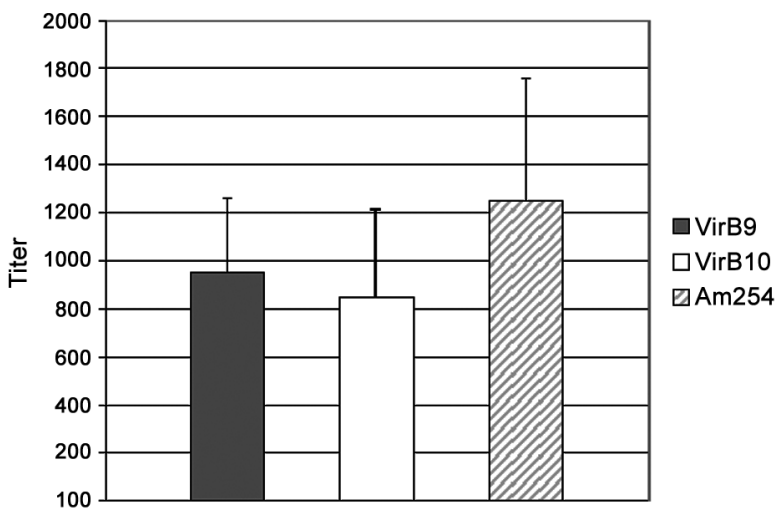

Fig. 3: IgG2 titers from 12 cattle naturally infected with Anaplasma marginale in ELISAs with recombinant VirB9, VirB10 and Am254.

TABLE I

Enzyme-linked immunosorbent assay (ELISAs) with recombinant VirB9, VirB10 and elongation factor Tu (EF-TU) from Rio Grande do Norte isolate of Anaplasma marginale, and sera from cattle experimentally infected with this isolate and from A. marginale free animals

\begin{tabular}{lcccccr}
\hline \multirow{2}{*}{$\begin{array}{l}\text { Status of cattle infection with } \\
\text { Anaplasma marginale }\end{array}$} & \multicolumn{3}{c}{ ELISA } \\
\cline { 2 - 7 } & \multicolumn{2}{c}{ VirB9 } & \multicolumn{2}{c}{ VirB10 } & EF-Tu \\
\cline { 2 - 7 } & Positive & Negative & Positive & Negative & Positive & Negative \\
\hline Positive & 72 & 0 & 72 & 0 & 72 & 0 \\
Negative & 1 & 71 & 0 & 72 & 71 \\
\hline
\end{tabular}

$a$ : defined by polymerase chain reaction (PCR) for major surface protein 5 (MSP5) gene.

TABLE II

ELISAs with recombinant VirB9, VirB10 and EF-Tu from Rio Grande do Norte isolate of Anaplasma marginale, and cattle sera from state of Alagoas

\begin{tabular}{lcccccr}
\hline Status of cattle infection with & \multicolumn{5}{c}{ ELISA } \\
\cline { 2 - 7 } & \multicolumn{2}{c}{ VirBa } & \multicolumn{2}{c}{ VirB10 } & EF-Tu \\
\cline { 2 - 7 } & Positive & Negative & Positive & Negative & Positive & Negative \\
\hline Positive & 61 & 9 & 61 & 9 & 61 & 9 \\
Negative & 0 & 70 & 0 & 70 & 70 \\
\hline
\end{tabular}

a: defined by ELISA with recombinant MSP5. 


\section{REFERENCES}

Ajayi SA, Wilson AJ, Campbell RS 1978. Experimental bovine anaplasmosis: clinico-pathological and nutritional studies. Res Vet Sci 25: 76-81.

Barbet AF, Palmer GH, Myler PJ, McGuire TC 1987. Characterization of an immunoprotective protein complex of Anaplasma marginale by cloning and expression of the gene coding for polypeptide Am105L. Infect Immun 55: 2428-2435.

Barros SL, Madruga CR, Araújo FR, Menk CF, de Almeida MA, Melo EP, Kessler RH 2005. Serological survey of Babesia bovis, Babesia bigemina, and Anaplasma marginale antibodies in cattle from the semi-arid region of the state of Bahia, Brazil, by enzyme-linked immunosorbent assays. Mem Inst Oswaldo Cruz 100: 513-517.

Brayton KA, Kappmeyer LS, Herndon DR, Dark MJ, Tibbals DL, Palmer GH, McGuire TC, Knowles DP Jr 2005. Complete genome sequencing of Anaplasma marginale reveals that the surface is skewed to two superfamilies of outer membrane proteins. Proc Natl Acad Sci USA 102: 844-849.

Brayton KA, Palmer GH, Brown WC 2006. Genomic and proteomic approaches to vaccine candidate identification for Anaplasma marginale. Expert Rev Vaccines 5: 95-101.

Brown WC, Palmer GH, Lewin HA, McGuire TC 2001. CD4+ T lymphocytes from calves immunized with Anaplasma marginale major surface protein 1 (MSP1), a heteromeric complex of MSP1a and MSP1b, preferentially recognize the MSP1a carboxyl terminus that is conserved among strains. Infect Immun 69: 6853-6862.

Brown WC, Shkap V, Zhu D, McGuire TC, Tuo W, McElwain TF, Palmer GH 1998. CD4+ T-lymphocyte and immunoglobulin G2 responses in calves immunized with Anaplasma marginale outer membranes and protected against homologous challenge. Infect Immun 66: 5406-5413.

Correa WM, Correa CN, Gottschalk AF 1978. Bovine abortion associated with Anaplasma marginale. Can J Comp Med 42: 227-228.

Dumler JS, Barbet AF, Bekker CP, Dasch GA, Palmer GH, Ray SC, Rikihisa Y, Rurangirwa FR 2001. Reorganization of genera in the families Rickettsiaceae and Anaplasmataceae in the order Rickettsiales: unification of some species of Ehrlichia with Anaplasma, Cowdria with Ehrlichia and Ehrlichia with Neorickettsia, descriptions of six new species combinations and designation of Ehrlichia equi and 'HGE agent' as subjective synonyms of Ehrlichia phagocytophila. Int J Syst Evol Microbiol 51: 2145-2165.

Frey A, Di Canzio J, Zurakowski D 1998. A statistically defined endpoint titer determination method for immunoassays. J Immunol Methods 221: 35-41.

Granato D, Bergonzelli GE, Pridmore RD, Marvin L, Rouvet M, Corthe'sy-Theulaz IE 2004. Cell surface-associated elongation factor Tu mediates the attachment of Lactobacillus johnsonii NCC533 (La1) to human intestinal cells and mucins. Infect Immun 72: 2160-2169.
Kocan KM, de la Fuente J, Guglielmone AA, Melendez RD 2003. Antigens and alternatives for control of Anaplasma marginale infection in cattle. Clin Microbiol Rev 16: 698-712.

Lopez JE, Palmer GH, Brayton KA, Dark MJ, Leach SE, Brown WC 2007. Immunogenicity of Anaplasma marginale type IV secretion system proteins in a protective outer membrane vaccine. Infect Immun 75: 2333-2342.

Lopez JE, Siems WF, Palmer GH, Brayton KA, McGuire TC, Norimine J, Brown WC 2005. Identification of novel antigenic proteins in a complex Anaplasma marginale outer membrane immunogen by mass spectrometry and genomic mapping. Infect Immun 73 : 8109-8118

Melo ESP, Araújo FR, Ramos CAN, Soares CO, Rosinha GMS, Elisei C, Madruga CR 2007. ELISA com MSP5 recombinante truncada para detecção de anticorpos contra Anaplasma marginale em bovinos bovinos. Pesq Vet Bras 27: 301-306.

Montenegro-James S, James MA, Benitez MT, Leon E, Baek BK, Guillen AT 1991. Efficacy of purified Anaplasma marginale initial bodies as a vaccine against anaplasmosis. Parasitol Res 77: 93-101.

Nilsson J, Nissen P 2005. Elongation factors on the ribosome. Curr Opin Struct Biol 15: 349-354.

Oberle SM, Barbet AF 1993. Derivation of the complete msp4 gene sequence of Anaplasma marginale without cloning. Gene 136: 291-294.

Oberle SM, Palmer GH, Barbet AF, McGuire TC 1988. Molecular size variations in an immunoprotective protein complex among isolates of Anaplasma marginale. Infect Immun 56: 1567-1573.

Palmer GH, Barbet AF, Kuttler KL, McGuire TC 1986. Detection of an Anaplasma marginale common surface protein present in all stages of infection. J Clin Microbiol 23: 1078-1083.

Palmer GH, McGuire TC 1984. Immune serum against Anaplasma marginale initial bodies neutralizes infectivity for cattle. J Immunol 133: 1010-1015.

Palmer GH, Rurangirwa FR, Kocan KM, Brown WC 1999. Molecular basis for vaccine development against the ehrlichial pathogen Anaplasma marginale. Parasitol Today 15: 281-286.

Rodriguez SD, Garcia Ortiz MA, Hernandez Salgado G, Santos Cerda NA, Aboytes Torre R, Canto Alarcon GJ 2000. Anaplasma marginale inactivated vaccine: dose titration against a homologous challenge. Comp Immunol Microbiol Infect Dis 23: 239-252.

Silva VM, Araújo FR, Madruga CR, Soares CO, Kessler RH, Almeida MA, Fragoso SP, Santos LR, Ramos CA, Bacanelli G, Torres RA 2006. Comparison between indirect enzyme-linked immunosorbent assays for Anaplasma marginale antibodies with recombinant major surface protein 5 and initial body antigens. Mem Inst Oswaldo Cruz 101: 511-516.

Tebele N, McGuire TC, Palmer GH 1991. Induction of protective immunity by using Anaplasma marginale initial body membranes. Infect Immun 59: 3199-3204. 